\title{
Cardiovascular Risk Factors in Childhood Claim for Public Health Policies
}

\author{
Tania L. R. Martinez, Abel Pereira, ${ }^{(1)}$ Anita L. R. Saldanha ${ }^{(0)}$ \\ $B P$ - A Beneficência Portuguesa de São Paulo, São Paulo, SP - Brazil \\ Short Editorial related to the article: Relationship between Dyslipidemia, Cultural Factors, and Cardiorespiratory Fitness in Schoolchildren
}

Obesity is presently a pandemic public health problem not only in developed countries but also in developing ones. As its incidence is increasing in childhood and adolescence as well this issue becomes alarming considering its evolution and associations. The multiple comorbidities such as hypertension, hyperlipidemia and insulin resistance that accompany obesity increase the risk of cardiovascular mortality whilst worsening quality of life in adults. ${ }^{1}$ It is always appropriate to reinforce the fact that the atherosclerotic process starts at an early stage in life ${ }^{2-5}$ as demonstrated in autopsies of children with strong association between LDL cholesterol levels prior to death and the presence of fatty streaks in the aorta. ${ }^{2}$ This observation has been documented in various reports in Brazil demonstrating that public health policies must be reinforced towards this problem. ${ }^{6-8}$

In different approaches in schoolchildren of a city in Sao Paulo for over ten years we have been studying the impact of biochemical, anthropometric, nutritional status, clinical, socio-cultural and economic conditions.

Interesting enough was the positive correlation between minimum wage salary and its multiples per family, indicating that probably expenses went up on unhealthy food in the richer groups. ${ }^{9,10}$ Passive smoking at home correlated with lower ranges of HDL Cholesterol. ${ }^{11}$ The distance between the urban and rural areas was divided into eight categories for comparison with Total Cholesterol values. The closer to rural areas the lower the Cholesterol and our understanding is that their diets were more adequate in terms of vegetables intake

\section{Keywords}

Cardiovascular Diseases/physiopathology; Child; Obesity; Risk Factors; Hypertension; Diabetes Mellitus; Hyperlipidemias; Insulin Resistance.

Mailing Address: Tania L. R. Martinez •

Rua Comandante Ismael Guilherme, 358. Postal Code 04031-120, Jardim

Lusitânia, São Paulo, SP - Brazil

E-mail: tamar@uol.com.br

DOI: $10.5935 / a b c .20190103$ and less processed food. For these conclusions, we needed a new statistical approach, a multilevel hierarchical model. ${ }^{12,13}$ Continuous intervention is given by means of weekly talks on the local radio, press releases, TV programs, participation in parents and teachers' meetings and periodically having ludic and playful camping with the students. Comparison of Total Cholesterol levels in the students of the same grades as of ten years earlier showed a statistically significant difference for the better, lower levels. ${ }^{14}$

Besides the already mentioned surveys in Brazil, programs with some slight differences are being carried out in other cities, such as Campinas ${ }^{15}$ and Sao Caetano do Sul.

The Brazilian Society of Cardiology enrolled the major part of the above-mentioned investigators in a unique programBrazilian Cardiology Society Goes to the Schools-, launched in 2017 together with the State of Sao Paulo Education Ministry. As from 2020, the plan is to have reached the five regions of Brazil.

The paper presented in this issue - Relationship between Dyslipidemia, Cultural Factors, and Cardiorespiratory Fitness in Schoolchildren - broadens importantly the spectrum of elements as to cardiovascular risk, mainly in the overweight or obese students. The Brazilian Society of Cardiology Goes to the Schools will contemplate incorporating the PROESP-BR test in its program. The hyperlipidemia finding of $41.9 \%$ is really alarming and close to $100 \%$ higher than the data that has been published. This really calls for immediate actions joining Ministeries of Health and of Education. Looking further into the article the attention is called to the investigators having a large range of spectrum to amplify their research as it is a relatively new observation among documentation of association with risk factors for atherosclerotic diseases. ${ }^{16}$

Articles on criterion-referenced cut points for cardiorespiratory fitness in children, ${ }^{17}$ sleep patterns, augmentation index, pulse wave velocity, insulin resistance, preschool children testing, cognition, arterial stiffness and so many others can be expected in the near future from the authors of this relevant and well-conducted paper. 


\section{References}

1. Pereira A, Guedes AD, Verreschi ITN, Santos RD, Martinez TLR. A obesidade e sua associação com os demais fatores de risco cardiovascular em escolares de Itapetininga, Brasil. Arq Bras Cardiol. 2009;93(3):253-60.

2. Martinez TLR. Condutas Clínicas nas Dislipidemias. Belo Horizonte: Health; 1997. 291p.

3. Kaprio J, Norio R, Pesonen E, Sarna S. Intimal thickening of the coronary arteries in infants in relation to family history of coronary artery disease. Circulation. 1993;87(6):1960-8.

4. Holman RL, McGill HC Jr, Strong JP, Geer JC. The natural history of atherosclerosis: the early aortic lesions as seen in New Orleans in the middle of the of the 20th century. Am J Pathol. 1958;34(2):209-35

5. Webber LS, Srinivasan SR, Wattigney WA, Berenson GS. Tracking of serum lipids and lipoproteins from childhood to adulthood. The Bogalusa Heart Study. Am J Epidemiol. 1991;133(9):884-99.

6. Gaya ACA. Projeto Esporte Brasil: manual de aplicação de medidas e testes, Normas e Critérios de Avaliação. Porto Alegre: UFRGS/Ministério da Saúde/ CNPQ; 2009

7. Barros MVG, Nahas MV. Medidas de Atividade Física: Teoria e Aplicação em Diversos Grupos Populacionais. Londrina: Midiograf; 2003.

8. Franca E, Alves JGB. Dislipidemia entre crianças e adolescentes de Pernambuco. Arq Bras Cardiol. 2006;87(6):722-7.

9. Pereira A, Martinez TLR. Epidemiological survey of doses of cholesterol, socio-economic and lifestyle in public school pupils in Brazilian city. Abstract. Atherosclerosis. 2015;241:e140.
10. Pereira A, Mello APQ, Martinez TLR, Guarnieri FH, Santos Filho RD. Impact of social and clinical parameters on Non-HDL cholesterol in school children. Abstract. Atherosclerosis. 2016;252:e45-e46.

11. Pereira A, Guarnieri FH, Abrão T, Martinez TLR. Lipoprotein changes in children related to home passive smoking. Abstract. Atherosclerosis. 2017;263:e215-6.

12. Pereira A, Guarnieri F, Mello APQ, Santos Filho R, Martinez TLR. Application of a multilevel hierarchical model to correlate total cholesterol in eight different settings. Abstract. Atherosclerosis. 2016;252:e85.

13. Pereira A, Guarnieri F, Mello APQ, Santos Filho R, Martinez TLR. Proposal of a new approach to access cholesterol ranges according to different conditions. Abstract. Atherosclerosis. 2016;252:e85.

14. Pereira, A, Martinez TLR. Impacto de uma década sobre níveis séricos de colesterol em crianças e adolescentes e suas correlações com perfil alimentar, estado nutricional e ingestão calórica. Abstract. Arq Bras Cardiol. 2014;103:60.

15. Turke, KC, Saraiva, D J B, Lantieri, C J B, Ferreira, JFM, Chagas, ACP. Fatores de risco Cardiovascular: O Diagnóstico e Prevenção Devem Iniciar Crianças e Adolescentes. Rev Soc Cardiol Estado de São Paulo 2019,29(1)-25-7

16. Reuter CP, Brand C, Silva PT, Reuter EM, Renner JD, Franke SI, et al. Relação entre dislipidemia. Fatores culturais e aptidão cardiorrespiratória em escolares. Arq Bras Cardiol. 2019; 112(6):729-736

17. Silva DAS, Lang JJ, Barnes JD, Tomkinson GR, Tremblay MS. Cardiorespiratory fitness in children: evidence for criterion-referenced cut-points. PLoS One. 2018;13(8):e0201048. 